School of Finance

University of St.Gallen

CONTAGIOUS BANK RUNS: EXPERIMENTAL EVIDENCE

MARTIN BROWN

STEFAN T. TRAUTMANN

RAZVAN VLAHU

WORKING PAPERS ON FinANCE No. 2012/7

SWISS INSTITUTE OF BANKING AND FINANCE (S/BF - HSG)

OCTOBER 2012 


\title{
Contagious Bank Runs: Experimental Evidence
}

\author{
Martin Brown*, Stefan T. Trautmann**, Razvan Vlahu***
}

October 30, 2012

\begin{abstract}
We conduct a laboratory experiment to examine under which circumstances a depositor-run at one bank may lead to a depositor-run at another bank. We implement two-person coordination games which capture the essence of the Diamond-Dybvig (1983) bank-run model. Subjects in the roles of followers observe the deposit withdrawal decisions of leaders before they make their own deposit withdrawal decisions. In one treatment followers know that there are no economic linkages between the leaders' and the followers' banks. In a second treatment followers know that there are economic linkages between the leaders' and the followers' banks. Our results suggest that deposit withdrawals are strongly contagious across banks only when depositors know that there are economic linkages between banks'. The contagion of withdrawals is by a change in beliefs about bank asset quality and in beliefs about the behavior of other depositors, with the latter channel being more pronounced. Our results reconcile panic-based and information-based explanations of bank runs.
\end{abstract}

JEL classification: D81; G21; G28

Keywords: Contagion; Bank runs; Systemic risk

\footnotetext{
*Brown: University of St. Gallen, Rosenbergstrasse 52, CH-9000 St. Gallen, email: martin.brown@unisg.ch. **Trautmann: CentER, Tilburg University, P.O. Box 90153, NL-5000LE Tilburg, email: s.t.trautmann@uvt.nl. ***Vlahu: De Nederlandsche Bank (DNB), P.O. Box 98, NL-1000AB Amsterdam, email: r.e.vlahu@dnb.nl. We thank Toni Ahnert, Peter Bossaerts, Carsten Schmidt and Tanju Yorulmazer, as well as seminar participants at the 7th Alhambra Experimental Workshop, and the 2012 Luxembourg Experimental Finance conference for helpful suggestions.
} 


\section{Introduction}

The recent financial crisis has demonstrated forcefully that we need a better understanding of the nature of systemic risk in the financial sector. Contagion, i.e. the situation in which the collapse of one financial institution leads to the default of other financial institutions, is arguably one key propagation mechanism of systemic risk. ${ }^{1}$ A growing theoretical literature in banking examines a wide range of channels through which contagion in the banking sector may occur, such as common asset exposure (Acharya, 2009; Ibragimov et al., 2011; Wagner, 2010), domino effects through the payments system or interbank markets due to counterparty risk (Allen and Gale, 2000; Dasgupta, 2004; Freixas and Parigi, 1998; Freixas et al., 2000; Rochet and Tirole, 1996), or price declines and resulting margin requirements (Brunnermeier and Pedersen, 2009). The empirical literature has focused on looking for evidence of contagion via direct linkages between banks (i.e., the mutual claims financial institutions have on each other) and showed that higher interbank exposures to a failed bank and weak bank fundamentals can generate large deposit withdrawals (Iyer and Peydro-Alcalde, 2011). ${ }^{2}$

Recent events in the banking sector in Europe suggest that changes in expectations and coordination failure of depositors may not only be a source of individual bank runs as in Diamond and Dybvig (1983), but may also be an important channel of systemic risk. ${ }^{3}$ Runs occurred at Spanish banks causing outflows of €74 billion in July 2012 only (which account for 7\% of Spain’s GDP). Amid problems in Spanish banking system (e.g., with Bankia and many cajas) large withdrawals took place at Santander’s UK subsidiary, although Santander is, arguably, the best positioned among Spanish banks to overcome the financial crisis due to its geographical diversification. However, contagion of deposit withdrawals across banks has so far received limited empirical attention. One key reason behind the lack of evidence on the contagion of runs across banks is that it is almost impossible to empirically identify contagion among depositors with field data. In particular, it is difficult to disentangle contagion as a cause of correlated deposit withdrawals across banks from other potential explanations:

\footnotetext{
${ }^{1}$ Allen et al. (2011, chapter 3) identify five sources for systemic risk: common exposure to asset price bubbles; mispricing of assets; fiscal deficits and sovereign default; currency mismatches in the banking system; maturity mismatches and liquidity provision.

${ }^{2}$ Several studies examine domino effects through the interbank market via simulations and conclude that such events are unlikely. See e.g. Furfine (2003), Mistrulli (2011), Upper (2011), Upper and Worms (2004), van Lelyveld and Liedorp (2006), Wells (2004).

${ }^{3}$ Financial Times (2008, 2009), Telegraph (2012a, 2012b).
} 
correlated liquidity shocks across households; correlated performance shocks across banks (i.e., due to macroeconomic shocks or changes in regulation); common exposure to asset shocks.

We employ a laboratory experiment to examine under which circumstances a bank run at one bank may lead to a bank run at another bank. In particular, we study whether bank runs may be contagious when (a) the economic fundamentals of banks are correlated (through common asset exposure), and (b) the economic fundamentals of banks are uncorrelated. We are thus able to identify whether depositor runs may spread across banks due to purely "psychological” linkages (e.g., observing an unrelated bank defaulting causes depositor anxiety),or whether bank runs are only contagious when there are economic linkages between the banks.

Our experiment is based on a two-person coordination game which captures the essence of the Diamond-Dybvig (1983) bank-run model. In each bank there are two depositors who decide simultaneously whether to keep their deposit in the bank or withdraw their deposit. If either depositor withdraws his funds, the bank must be liquidated. In this game both a "good" equilibrium (neither depositor withdraws) and a "bad" equilibrium (both depositors withdraw) exists. In our experiment there are two types of depositors: leaders and followers. Subjects in the roles of followers observe the outcome of a coordination game of a pair of leaders before they make their own deposit withdrawal decisions. In one treatment of the experiment followers know that there are no economic linkages between the leaders' and the followers' banks. In a second treatment followers know that there are economic linkages (i.e., common asset exposure) between the leaders' and the followers' banks. Comparing the two treatments we can assess whether the contagion of deposit withdrawals (from leaders to followers) occurs only when depositors know that there are economic linkages between banks, or whether contagion due to purely psychological linkages is also common.

Our results suggest that deposit withdrawals can be strongly contagious across banks when there are economic linkages between banks' balance sheets. By contrast, we find no evidence contagion of deposit withdrawals between banks without economic linkages. In our treatment with economic linkages we find evidence for fundamentals-based contagion (i.e., depositors update their belief about the asset quality of the bank) and strategic contagion (i.e., they update their beliefs about the withdrawal behavior of the other depositor at their bank). In our experiment, strategic contagion accounts for a much larger share of observed withdrawals than fundamentals-based contagion. 
Our findings inform the theoretical debate about panic-driven vs. information-driven bank-runs. Diamond and Dybvig (1983) provide a model of sunspot or panic driven bankruns in which a coordination failure of non-liquidity constrained depositors can lead to the liquidation of a solvent bank. Chari and Jagannathan (1988) by contrast provide a model in which imperfect information about the fundamentals of a bank can lead to a run by depositors on a solvent bank. ${ }^{4}$ Our experimental results reconcile these different views and are consistent with theories of financial contagion due to information about bank defaults when banks have common exposure (Ahnert and Georg, 2012; Chen, 1999). We find evidence for contagion of panic-driven deposit withdrawals across banks, driven by updated beliefs about the behavior of other depositors. However, this mechanism is only active if the depositors know that their bank has linkages with the bank for which they observed a bank run. That is, beliefs are only affected if the bank run reveals relevant information about the behavior of depositors at other, similar banks.

Our study complements the empirical work on contagion of bank runs. Calomiris and Mason (1997) compare the fundamentals of banks which survived the 1932 Chicago Bank Crisis and compare them to those banks which failed during this period. They find that banks which survived the crisis had stronger fundamentals. Their evidence suggests that while solvent banks did experience substantial deposit withdrawals during this period, these withdrawals did not lead to a significant number of failures of ex-ante solvent banks. Saunders and Wilson (1996) also compare deposit withdrawals from failed and non-failed banks during the US great depression. They find that failed banks experience larger withdrawals throughout the 1929-1933 period, suggesting that withdrawals were predominantly information driven. However, during the height of the depression (1930-1932) deposit withdrawals did also spread from failed to solvent banks, indicating some contagion during this period. Our experimental results suggest that depositors may have perceived economic linkages between insolvent and solvent banks, making withdrawals at the former relevant for their beliefs. In a recent paper Iyer and Puri (2012) provide household-level evidence on the determinants of a bank run on an Indian cooperative bank in 2003, triggered by the failure of an unrelated (i.e., no fundamental linkages such as interbank exposures) neighboring bank. Their evidence shows that personal networks among depositors can lead to

\footnotetext{
${ }^{4}$ For other models of coordination failure among depositors see Bryant (1980), Postlewaite and Vives (1987) or Goldstein and Pauzner (2005). For other models of information-driven bank runs see Jacklin and Bhattacharya (1988) or Calomiris and Kahn (1991). Freixas and Rochet (2008) and Degryse et al. (2009) survey the theoretical and empirical literature on bank runs, respectively.
} 
contagion of deposit withdrawals within a given bank. De Graeve and Karas (2010) use methods from macroeconomics and implement a structural VAR model using Russian deposit market data over the period 2002-2007. They argue that even though banks' fundamentals play an important role, with insolvent banks facing more severe deposit outflows than solvent banks, the panic effect is more important than information about fundamentals.

Recent experimental studies examine the economic and behavioral determinants of runs on individual banks. ${ }^{5}$ Implementing a repeated 10-person coordination game, Madies (2006) shows that sunspot bank runs can occur and that a suspension of convertibility or a full (as opposed to partial) deposit insurance may be required to prevent bank runs. Garratt and Keister (2009) examine bank runs in the context of a 5-person coordination game. They expand upon the framework of Madies (2006) by introducing stochastic liquidity shocks of depositors. They show that when liquidity demand is not subject to stochastic shocks panicdriven bank runs are unlikely to occur. With stochastic liquidity shocks, however, selffulfilling bank runs are frequent. Schotter and Yorulmazer (2009) examine the dynamics of runs on individual banks in a 6-person bank-run game with sequential withdrawal opportunities. Their results suggest that when depositors expect to acquire information about the solvency of the bank they may be more willing to temporarily restrain from withdrawing their deposits. As a consequence the presence of informed depositors can mitigate the speed and severity of bank runs. Similarly, Kiss et al. (2011, 2012) study how observability of depositors' withdrawals within a given bank affects the likelihood of bank runs, and how the interaction between observability and deposit insurance affects this likelihood. They implement a 3-person coordination game, in which one depositor is always impatient (i.e., she always withdraws the deposit), and show that non-observability of other depositors' decisions makes banks more fragile. However, they argue that partial deposit insurance can prevent bank runs when depositors are informed about other depositors' withdrawals decisions, and that full insurance is necessary when these decisions are unobservable.

Our paper contributes to the above literature by providing, to our knowledge, the first evidence on the drivers behind the contagion of deposit runs from one bank to another. In particular we can disentangle whether deposit withdrawals are contagious across banks due to

\footnotetext{
${ }^{5}$ Besides studying bank runs, laboratory experiments have been recently employed in the empirical literature on financial intermediation to examine the strategic behavior of borrowers (Trautmann and Vlahu, 2011) and the impact of information sharing and long-term banking relationships on borrower and lender behavior (Brown and Zehnder 2007, 2010; Fehr and Zehnder, 2009).
} 
pure psychological effects or whether contagion only arises when depositors know that the economic fundamentals of the banks are linked. Our results suggest that the latter is the case.

The rest of the paper is organized as follows. Section 2 outlines our experimental design and Section 3 presents our predictions for each treatment. Results are presented in Section 4. Section 5 discusses our results and concludes.

\section{Experimental Design}

\subsection{The Depositors' Coordination Problem}

Our experimental design is based on a two-person coordination game which captures the essence of the Diamond and Dybvig (1983) model of bank runs. In this game there are two depositors, Depositor A and Depositor B, each with a deposit of value $V$ in the bank. Both depositors decide simultaneously whether to keep their deposit in the bank until maturity, or to withdraw their funds. We implement this bank-run game without deposit insurance and apply a sequential service constraint: If both depositors keep their funds in the bank, the bank does not have to liquidate any investments and both depositors receive a payoff $R$, which is larger than $V$. If either depositor withdraws his deposit the bank is liquidated. We assume that the liquidation value of the bank's investment $L$ is less than $V$. As a consequence, if only one depositor withdraws that depositor receives a payoff of $L$ and the other depositor receives 0 . If both depositors withdraw, each receives a payoff of $L / 2$.

Figure 1 presents the payoff matrix of this two-person bank-run game for which there are two symmetric pure-strategy equilibria: [Keep deposit; Keep deposit] and [Withdraw; Withdraw]. In the experiment, $R$ takes either the value $R_{\text {strong }}=60$ or $R_{\text {weak }}=50$, indicating a bank with a strong or weak portfolio of assets. The liquidation value is set at $L=40$.

\begin{tabular}{|l|c|c|}
\hline Depositor A & Keep deposit & Withdraw \\
\hline Keep deposit & $R, R$ & $0, L$ \\
\hline Withdraw & $L, O$ & $L / 2, L / 2$ \\
\hline
\end{tabular}

Figure 1: The Depositors’ CoORdinAtion ProBlem 


\subsection{Treatments}

The aim of our study is to examine under which circumstances a depositor run on one bank may lead to a depositor run on another bank. To this end we employ a sequential structure, in which two pairs of subjects play the bank-run game after each other. The first pair of subjects are called the leaders. The second pair of subjects are called the followers. In all treatments the leaders are informed about the structure of the game as displayed in Figure 1 and are informed about whether $R$ takes either the value $R_{\text {strong }}=60$ or $R_{\text {weak }}=50$ for their bank. With this information these two subjects simultaneously make their decision to keep their deposits in their bank or withdraw them.

The information set of the followers is varied across treatments. Our first treatment is called the No-Linkages treatment. In this treatment, the result of the leaders' game (i.e., the number of withdrawals that occurred $-0,1$, or 2 ) is communicated to both followers and becomes common knowledge. Both followers are also informed that the leaders knew the asset quality of their bank before they made their decisions. The followers are informed about the payoff structure of the game and are also informed that the probability of their bank having strong or weak assets is $1 / 2$ (see details in Section 2.3). Importantly, followers are informed that the realization of the actual asset quality of their bank is independent of that of the leaders' bank. It is thus common knowledge among the followers that there are no economic linkages between their bank and that of the leaders. With this information the followers each simultaneously make a decision to withdraw or keep their deposit. Note that in this treatment the information about the withdrawal behavior of the leaders does not provide the followers with any information about the quality of their own bank. Thus any impact of the behavior of the leaders on the behavior of the followers would be driven entirely by psychological as opposed to economic linkages, and presumably only propagated on through strategic contagion (see Section 3). ${ }^{6}$

Our second treatment is called the Linkages treatment. As in the No-Linkages treatment the followers are informed about the number of withdrawals that occurred in the leaders' game, and that the leaders knew the asset quality of their bank before they made their decisions. They are further informed about the payoff structure of the game and that the exante probability of $R$ taking either the value $R_{\text {strong }}=60$ or $R_{\text {weak }}=50$ is equal. In contrast to the

${ }^{6}$ For instance, the psychological effect may obtain from an updated belief of how people typically behave in such coordination problems, or from making one equilibrium more focal in the perception of followers. 
No-Linkages treatment followers are informed that the asset quality of their bank is identical to that of the leaders. In this treatment it is thus common knowledge among the followers that there are economic linkages between their bank and that of the leaders. Given that the leaders know the asset quality of their bank before they make their decisions, the followers can use the information about the withdrawal behavior of the leaders to update their belief about whether their own bank has weak or strong assets.

Our third treatment is called the Baseline treatment. In this control treatment the followers are not informed about the behavior of the leaders. Thus their behavior is shielded both from psychological and economic contagion. This treatment serves as a benchmark for the behavior of subjects in our bank-run game with uncertain payoffs. Table 1 summarizes our experimental treatments.

TABLE 1. TREATMENTS

\begin{tabular}{l|c|c|c}
\hline \hline \multicolumn{1}{|c|}{ Treatment } & No-Linkages & Linkages & Baseline \\
Conditions for followers & yes & yes & yes \\
\hline $\begin{array}{l}\text { Uncertainty about asset quality of } \\
\text { their bank }\end{array}$ & yes & yes & no \\
\hline Observe leaders behavior & no & yes & no \\
\hline $\begin{array}{l}\text { Common knowledge that the asset } \\
\text { quality of leader-bank and } \\
\text { follower-bank are identical }\end{array}$ & & & \\
\hline \hline
\end{tabular}

\subsection{Procedures}

We conducted 14 experimental sessions, with either 16 or 20 subjects in each session. In total 264 undergraduate students of the University of Amsterdam participated in our experiment. The experiment was programmed and run using z-Tree software (Fischbacher, 2007). ${ }^{7}$ Each session consisted of two parts. In part I participants played two rounds of the depositors' coordination game, while in part II they took part in an individual decision task.

In part I of the experiment, the 16-20 subjects were randomly matched in groups of four players. At the beginning of the session, one group of four players was randomly assigned to the role of leaders. The other three or four groups were assigned the role of

\footnotetext{
${ }^{7}$ Instructions are available online at: https://dl.dropbox.com/u/11242744/20121030_BTV_onlineappendix.pdf
} 
followers. ${ }^{8}$ The roles assigned were fixed for both rounds. In total, 60 subjects were assigned the role of leaders and 184 the role of followers. In each session all players assigned the role of followers played the same treatment, as shown in Table 2.

TABLE 2. SESSIONS AND TREATMENTS

\begin{tabular}{cccc}
\hline \hline Sessions & Treatment & Number of leaders & $\begin{array}{c}\text { Number } \\
\text { of followers }\end{array}$ \\
\hline 1, 2, 3 & Baseline & - & 60 \\
$4,5,6,10,13$ & No Linkages & 20 & 72 \\
$7,8,9,11,12$ & Linkages & 20 & 72 \\
14 & (only leaders game) & 20 & - \\
\hline
\end{tabular}

Subjects received written general instructions at the beginning of the session that were also read aloud. At the beginning of part I, subjects received the specific instructions for the bank-run game directly on-screen. Leaders received different instructions on screen than followers. Importantly, leaders did not know that their choices would later be communicated to followers, to avoid any effects of such observability on their behavior. Followers were informed that leaders did not know that their choices were observed by others. The bank-run game was framed in the banking context. Before part I of the experiment started, each subject had to pass a test with control questions for which they had to calculate the payoffs for both players to make sure that they understood the payoff structure and the decision process. These practice questions were not paid, but the payoffs in these test questions were identical in size and structure to the game studied in the real task. Only after all subjects correctly calculated the payoffs did the program continue to the main task.

As mentioned above, each subject played two rounds of the coordination game. Within each 4-person-group subjects were matched such that they played with a different participant within their group in each of the two rounds. This procedure implies that for the group of leaders in each session we have four observations of the bank-run game. In the No-Linkages and Linkages treatments we showed the outcome of each of these games to a different group of followers (see Figure 2).

In each session two of the leaders games were implemented with strong assets $\left(R_{\text {strong }}=60\right)$ and two were implemented with weak assets $\left(R_{\text {weak }}=50\right)$. Importantly, which of

\footnotetext{
${ }^{8}$ There were two exceptions to this design. First, in all the sessions in which treatment Baseline was played, there were no leaders, since followers did not receive any information about the leaders' game. Second, in order to secure comparability, we run a separate session in which all the 20 subjects were assigned the role of leaders.
} 
the leaders games was implemented with strong or weak assets was determined randomly prior to the beginning of each session. For each follower group the quality of bank assets was constant in both rounds. In the Baseline and No-Linkage treatment the quality of bank assets was randomly determined prior to the begin of the session: Two groups of followers were assigned strong bank assets, while the other two were assigned to weak bank assets. In the Linkages-treatment the quality of bank assets was directly linked to that of the observed followers, and thus also randomly determined prior to the begin of the session.

All followers we informed about the process of determining the quality of bank assets for their group. This allowed us to (i) refer in the instructions to actual numbers of banks that are weak or strong, and (ii) make sure that in each session there was an equal number of weak and strong banks for leaders, and followers were aware of that fact.

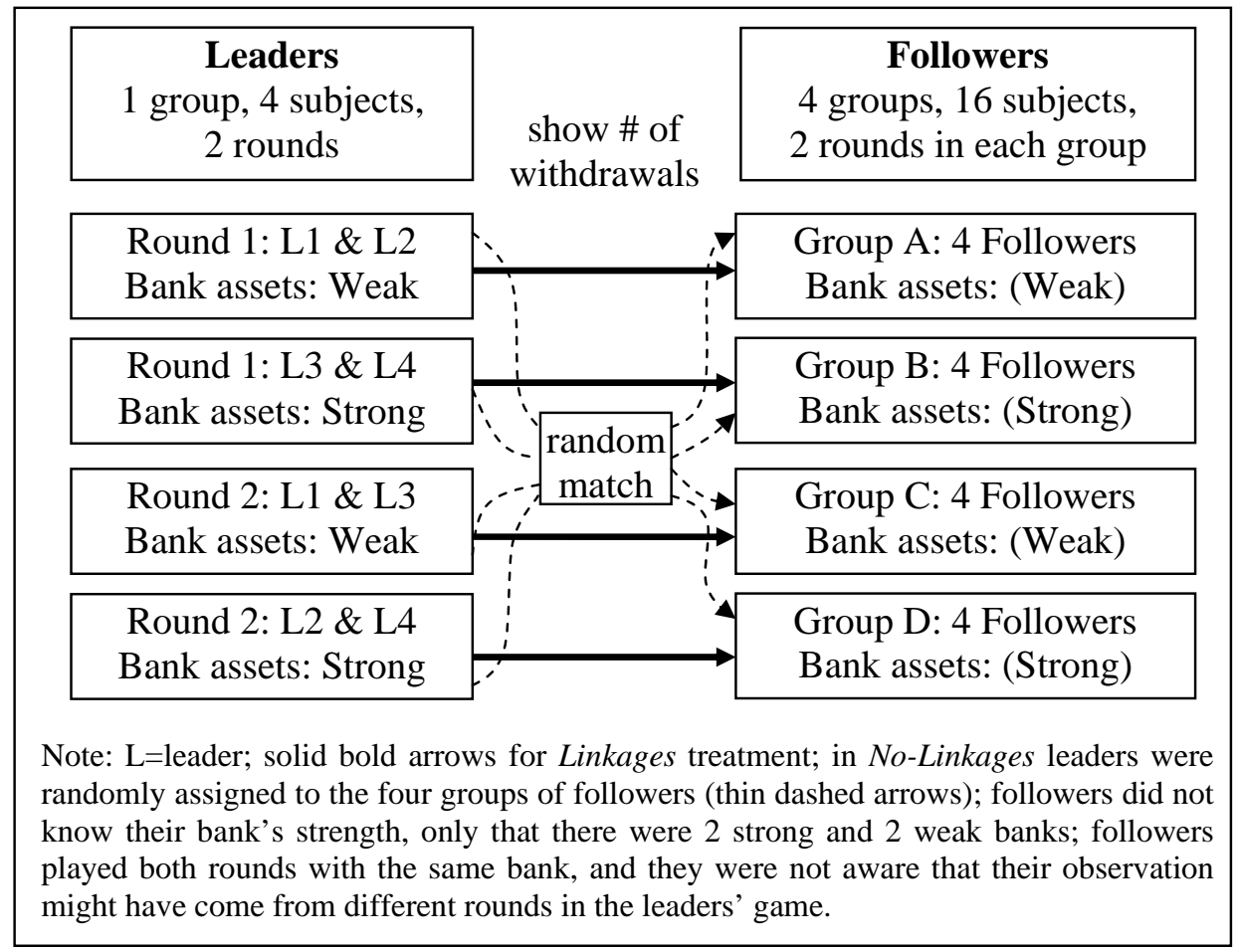

FIGURE 2: INFORMATION TRANSMISSION

Each subject in the role of a follower made a decision to withdraw or keep their deposit in each of the two rounds. Prior to each decision we elicited each subject's beliefs about the behavior of the other depositor in their bank and the asset quality of the bank. First, we asked subjects to express their beliefs about how likely it was that their bank has strong 
assets. Then all followers had to state the likelihood that the other depositor with whom they are matched with is withdrawing her deposit. Beliefs were measured on a 7-point Likert scale, and normalized to a scale from 0 (very unlikely) to 1(very likely).

Depending on the outcome of the bank-run game, subjects could earn between 0 and 60 experimental units in each round (Figure 1). At the end of the experiment one round was randomly selected for real payment to avoid wealth effects. Each experimental unit translated into $€ 0.10$ at the end of the experiment for real payment, on top of a show up fee of $€ 7$.

\subsection{Elicitation of Loss Attitudes}

Loss aversion has been found to affect behavior in coordination games, and we therefore control for it in the current experiment. ${ }^{9}$ In part II of the experiment each subject completed an individual decision task, which was aimed at eliciting subjects' attitude towards losses (Gächter et al., 2007). We elicit loss attitudes by offering subjects a series of risky lotteries that give an equal chance of either a gain or a loss in terms of experimental units. For each lottery, subjects could choose to play or not to play (see Table 3). Subjects were free to accept or reject any prospect, that is, we did not require single switching from acceptance to rejection as the loss increases along the list. For losses smaller than 27 , rejecting to play the prospect implies a significant reduction in the expected value that may be explained more easily by a gain-loss framing and a kinked utility function of wealth changes, than by a concave utility of wealth. We call subjects who reject more lotteries in this task more loss averse. Subjects earned experimental units according to their decision in all six choices, depending on the outcome of the risky prospects.

TABLe 3. ChOICE List MeAsure of LOSS AVERSiON

\begin{tabular}{lcl}
\hline Lottery $(50 \%-50 \%)$ & Accept to play? \\
\hline Lose 9 units or Win 27 units & Yes O & No O \\
Lose 15 units or Win 27 units & Yes O $\quad$ No O \\
Lose 18 units or Win 27 units & Yes O $\quad$ No O \\
Lose 21 units or Win 27 units & Yes O No O \\
Lose 27 units or Win 27 units & Yes O No O \\
Lose 33 units or Win 27 units & Yes O No O \\
\hline
\end{tabular}

${ }^{9}$ See Cachon and Camerer (1996) and Rydval and Ortmann (2005). 


\section{Predictions}

We are interested in the effects of the leaders' withdrawal behavior on followers. Note that both banks in the current settings are solvent (i.e., they can fully repay depositors if none of them withdraws prematurely). However, previous literature has found that withdrawals happen, and that bank runs are affected by the relative payoff dominance of the nowithdrawal equilibrium [Keep deposit; Keep deposit] and the risk dominance of the bank-run equilibrium [Withdraw; Withdraw]. In our experiment the no-withdrawal equilibrium is less payoff dominant, and the bank-run equilibrium is more risk dominant when bank assets are weak $\left(R_{\text {weak }}=50\right)$ than when bank assets are strong $\left(R_{\text {strong }}=60\right) .{ }^{10}$ We therefore expect that leaders are more likely to withdraw when they know their bank has weak assets than when they know their bank has strong assets. More importantly, we expect that the stronger the belief of a follower that his bank has weak assets the more likely that follower is to withdraw. In addition, the stronger the belief of a follower that the other depositor in his bank believes the bank has weak assets, the more likely the depositor is to withdraw.

In the No-linkages treatments and Linkages treatments we expect the beliefs of followers and thus the withdrawal behavior of followers to be affected by the withdrawals they observe in the leaders game. However, the impact of observed withdrawals by leaders on followers' beliefs and behavior should differ between the two treatments as suggested in Hypothesis 1 and Hypothesis 2.

HyPOTHESIS 1 (FOLLOWERS IN THE NO-LINKAGES TREATMENT): Followers' withdrawal behavior is affected by the number of withdrawals they observe in the leaders' game, because it may change their belief about the withdrawal propensity of the other follower in their bank.

Followers in the No-Linkages treatment make withdrawal decision not knowing the strength of their bank. They receive information about the behavior of a pair of depositors (leaders) at an economically unrelated bank. This information should not affect the followers' assessment of the asset quality of their own bank. However, if one follower believes that the other follower in his bank is more likely to withdraw after observing 2 leaders withdraw than after observing 0 leaders withdraw then this follower may be more likely to withdraw himself. Thus even in the absence of economic linkages between banks, contagion of withdrawals between leaders and followers is feasible due to purely strategic contagion:

\footnotetext{
${ }^{10}$ Camerer (2003) discusses equilibrium selection criteria in coordination games.
} 
economically irrelevant information affects the beliefs of depositors about how other depositors in their bank may behave.

HyPOTHESIS 2 (FOLLOWERS IN THE LINKAGES TREATMENT): Followers' withdrawal behavior is affected by the number of withdrawals that they observe in the leaders' game because it may change their belief about the withdrawal propensity of the other follower in their bank and it may change their belief about the asset-quality of the bank.

As with followers in the No-Linkages treatment, the withdrawal behavior of followers in the Linkages treatment may be affected by strategic contagion. In addition though, the Linkages treatment may lead to fundamental-based contagion of withdrawals across banks: Followers receive information about the behavior of a pair of depositors (leaders) at a bank with identical fundamentals as their own bank. This information allows followers to update their beliefs about the asset quality of their own bank, and differences in the payoff and risk dominance criteria may affect their withdrawal behavior.

Based on Hypotheses 1 and 2 we expect to see more contagion of deposit withdrawals from leaders to followers in the Linkages treatment than in the No-Linkages treatment. That is the propensity of followers to withdrawals should be more strongly related to the number of leaders' withdrawals observed in the former than in the latter treatment. First, in the NoLinkages treatment fundamentals-based contagion is not feasible whereas it is in the Linkages treatment: The number of observed leaders' withdrawals should induce followers in the Linkages treatment to update their belief about the asset quality of their bank. For a given belief about the behavior of the other follower, this updating of beliefs about asset-quality should affect the propensity to withdraw. Second, strategic contagion may be stronger in the Linkages treatment than in the No-Linkages treatment: strategic contagion relies on a follower updating his belief that the other follower will withdraw after observing the number of withdrawals by leaders. It seems reasonable to assume that a follower is more likely to expect the other follower to change his withdrawal behavior when that follower knows the asset-quality of the leader and follower banks are identical.

\section{Results}

We first present the withdrawal behavior for leaders. Contagion results for followers are presented in Section 4.2. Here we only use data of the first rounds of followers' games, which 
are only affected by the observed withdrawals by the leaders. In Section 4.3 we study potential within-bank spillover effects triggered by contagion, using the data of the second round followers' games.

\subsection{Leaders Withdrawal Behavior}

Table 4 shows withdrawals behavior of leaders, contingent on the asset-quality of the bank. As expected, we find higher rates of withdrawal when the asset-quality of the banks is weak. A probit regression confirms a mild increase in withdrawals for weak banks after controlling for loss aversion and round effects. Leaders are $13.6 \%$ more likely to withdraw for a weak bank $(\mathrm{p}=.0875)$. In addition a 1 point increase in our measure of loss aversion increases the probability of withdrawing by $7.6 \%(\mathrm{p}=.037) .{ }^{11}$

TABLE 4. WITHDRAWALS - LEADERS

\begin{tabular}{cll}
\hline \hline & Strong bank & Weak bank \\
Withdrawals round 1 & $23.3 \%$ & $36.6 \%$ \\
Withdrawals round 2 & $16.7 \%$ & $26.7 \%$ \\
\hline \hline
\end{tabular}

The leaders' data show that the calibration of the coordination game was successful. We obtain variation in the withdrawals, with overall 68 cases of no withdrawals, 64 cases with 1 withdrawal, and 12 cases with two withdrawals communicated to the followers. While the withdrawal rate is higher for banks with weak assets, the observed number of withdrawals is by no means a perfect signal of the asset-quality. This finding is important, as otherwise contagion would almost trivially be obtained in the Linkages treatment.

\subsection{Contagion of Deposit Withdrawals across Banks}

Our analysis of contagion across banks is based on the first-round behavior of followers in the Baseline, No-Linkages and Linkages treatments. We ignore the second-round behavior of followers in order to not confound contagion across banks (i.e., from leaders to followers), with potential spillover effects within banks (i.e., from followers in round 1 to followers in round 2).

${ }^{11}$ All tests in this paper are two-sided tests. 
TABle 5: CONTAGion, WithdRAWALS AND BELIEFS - Summary STATISTiCS

\begin{tabular}{lllll|lllll|l}
\hline \multicolumn{1}{r}{ Treatment } & \multicolumn{4}{c}{ No-Linkages (n=72) } & \multicolumn{3}{c}{ Linkages (n=72) } & Baseline \\
\# observed withdrawals & 0 & 1 & 2 & Mean & 0 & 1 & 2 & Mean & n.a. \\
\multicolumn{1}{c}{ Observations } & $\mathrm{n}=44$ & $\mathrm{n}=24$ & $\mathrm{n}=4$ & $\mathrm{n}=72$ & $\mathrm{n}=24$ & $\mathrm{n}=40$ & $\mathrm{n}=8$ & $\mathrm{n}=72$ & $\mathrm{n}=60$ \\
\hline Withdrawals & $15.9 \%$ & $25.0 \%$ & $0.0 \%$ & $18.0 \%$ & $12.5 \%$ & $50.0 \%$ & $62.5 \%$ & $39.0 \%$ & $23.3 \%$ \\
\hline Belief other withdraws & .375 & .438 & .375 & .40 & .313 & .517 & .563 & .45 & .308 \\
\hline Belief bank strong & .557 & .556 & .583 & .56 & .604 & .496 & .470 & .53 & .547 \\
\hline \hline
\end{tabular}

Notes: The table reports the percentage of followers who withdraw in round 1, beliefs about the other depositor, and beliefs about the bank, conditioned on the treatment and the number of withdrawals which they observe. Withdrawal is a dummy variable which is 1 if the subject withdraws and 0 otherwise. Belief other withdraws captures the belief of the subject (as a probability) that the other depositor in his bank will withdraw. Belief bank strong captures the belief of the subject (as a probability) that the bank has strong assets (i.e., that $\mathrm{R}=60$ ). 
Table 5 provides summary statistics of the behavior and beliefs of followers by treatments, conditioned on the number of observed withdrawals by leaders. On average, with no economic linkages, neither the withdrawals nor the beliefs systematically differ as a function of the observed withdrawals in the leaders' game, and both are indistinguishable from the Baseline treatment. That is, there is no evidence for contagion in the No-Linkages treatment. By contrast, in the Linkages treatment we find a strong positive correlation between leaders' and followers' withdrawal behavior ( $\mathrm{p}=.002$, Fisher exact test). The propensity of a follower to withdraw in the Linkages treatment is less than $13 \%$ if she observes no leader withdrawing, and rises to $50 \%$ and $62.5 \%$ if the follower observes one and two leaders withdrawing, respectively. A comparison with the Baseline treatment results shows that contagion seems to work in both directions, reducing withdrawals when all leaders keep their funds in the bank, and increasing withdrawals as soon as withdrawals by leaders are observed. However, only the latter effect is statistically significant ( $\mathrm{p}=.041$, Fischer exact test, pooled for 1 or 2 observed withdrawals).

TABle 6: Contagion AND WithdraWAls - Multivariate Results

\begin{tabular}{|c|c|c|c|c|}
\hline Treatment & $\begin{array}{l}\text { Baseline } \\
\text { [1] }\end{array}$ & $\begin{array}{l}\text { No } \\
\text { Linkages } \\
{[2]}\end{array}$ & $\begin{array}{l}\text { Linkages } \\
\text { [3] }\end{array}$ & $\begin{array}{l}\text { No-Linkages \& } \\
\text { Linkages } \\
\text { [4] }\end{array}$ \\
\hline Leaders’ withdrawals & & $\begin{array}{l}-0.014 \\
{[0.0660]}\end{array}$ & $\begin{array}{l}0.309 * * * \\
{[0.104]}\end{array}$ & $\begin{array}{l}-0.00626 \\
{[0.0648]}\end{array}$ \\
\hline Loss aversion & $\begin{array}{l}0.019 \\
{[0.0469]}\end{array}$ & $\begin{array}{l}0.0467 \\
{[0.0298]}\end{array}$ & $\begin{array}{l}0.0395 \\
{[0.0425]}\end{array}$ & $\begin{array}{l}0.0443 \\
{[0.0292]}\end{array}$ \\
\hline Linkages & & & & $\begin{array}{l}0.0016 \\
{[0.139]}\end{array}$ \\
\hline Linkages * Leaders withdrawals & & & & $\begin{array}{l}0.285^{* * *} \\
{[0.105]}\end{array}$ \\
\hline Linkages $*$ Loss aversion & & & & $\begin{array}{l}-0.0123 \\
{[0.0475]}\end{array}$ \\
\hline Observations & 60 & 72 & 72 & 144 \\
\hline R-squared (pseudo R2) & 0.00332 & 0.03 & 0.12 & 0.15 \\
\hline Model & Probit & Probit & Probit & OLS \\
\hline
\end{tabular}

Notes: This table examines the withdrawal behavior of followers in the first round only. The dependent variable in this table is Withdrawal. Columns 1-3 report marginal effects of probit estimations. Column 4 reports OLS estimates. Robust standard errors reported in brackets. *, **, *** indicate significance at the $10 \%, 5 \%$ and $1 \%$ level, respectively. 
Table 6 presents a multivariate analysis of withdrawal behavior by followers in the Baseline, Linkages and No-Linkages treatments. Columns 1 to 3 present marginal effects of probit estimates for each treatment separately. Column 4 presents pooled OLS estimates for the Linkages and No-Linkages treatments. ${ }^{12}$ Robust standard errors are displayed in brackets. The estimates reported for Leaders' withdrawals in columns 2 and 3 confirm that the number of leaders' withdrawals seen be followers affects their withdrawal behavior in the Linkages treatment, but not in the No-Linkages treatment. This result is captured by the significant interaction term Linkages * Leaders' withdrawal in the pooled regression reported in column 4.

The fact that we find no contagion of withdrawals in the No-Linkages treatment suggests that in this market condition the number of leaders withdrawals had no impact on the beliefs of followers about the asset-quality of the bank or their belief about the propensity of the other follower to withdraw. While the first effect (fundamentals-based contagion) was ruled out in this condition by design, the second effect suggests an absence of strategic contagion. This is confirmed by Table 5 which shows that beliefs about the withdrawal propensity of the other follower are not related to the number of observed withdrawals in NoLinkages.

As suggested in Section 3, stronger contagion in the Linkages treatment than in the NoLinkages treatment may occur through fundamentals-based contagion and/or stronger strategic contagion. That is followers are more likely to update their beliefs about (i) the asset-quality of the bank and (ii) the propensity of the other follower to withdraw. We find evidence for both of these complementary channels: Compared to the Baseline treatment, depositors in the Linkages treatment become more pessimistic about the other depositor after observing at least one withdrawal ( $\mathrm{p}<.001$, Mann-Whitney $U$ test), but not more optimistic when zero withdrawals are observed $(\mathrm{p}=.954)$. Perceptions about the strength of the bank become more optimistic when zero withdrawals are observed and more pessimistic when at least one withdrawal is observed, but these effects are only marginally significant compared to Baseline $(\mathrm{p}=.100$ and $\mathrm{p}=.124)$.

\footnotetext{
${ }^{12}$ We report linear estimation for the dependent variable Withdrawal in model 4 because of the difficulty in interpreting the marginal effects of interaction terms in non-linear models (Ai and Norton, 2003). Probit estimates for column 4 yield qualitatively identical results.
} 
TABle 7: Contagion Through Beliefs

\begin{tabular}{|c|c|c|c|c|c|c|}
\hline \multirow[b]{2}{*}{ Dependent Variable } & \multicolumn{3}{|c|}{ Linkages } & \multicolumn{3}{|c|}{ No-Linkages } \\
\hline & $\begin{array}{c}\text { Belief Bank } \\
\text { Strong } \\
\text { [1] }\end{array}$ & $\begin{array}{r}\text { Belief Other } \\
\text { Withdraw } \\
\text { [2] }\end{array}$ & $\begin{array}{r}\text { Withdraw } \\
\text { [3] }\end{array}$ & $\begin{array}{l}\text { Belief Bank } \\
\text { Strong } \\
\end{array}$ & $\begin{array}{c}\text { Belief Other } \\
\text { Withdraw } \\
{[5]}\end{array}$ & $\begin{array}{r}\text { Withdraw } \\
\text { [6] }\end{array}$ \\
\hline Leader' withdrawals & $\begin{array}{r}-0.0850^{* *} \\
{[0.0402]}\end{array}$ & $\begin{array}{c}0.147^{* *} \\
{[0.0615]}\end{array}$ & & $\begin{array}{r}-0.000642 \\
{[0.0370]}\end{array}$ & $\begin{array}{r}0.0316 \\
{[0.0517]}\end{array}$ & \\
\hline Belief bank strong & & & $\begin{array}{r}0.149 \\
{[0.381]}\end{array}$ & & & $\begin{array}{r}-0.00478 \\
{[0.257]}\end{array}$ \\
\hline Belief others withdraw & & & $\begin{array}{r}1.498 * * * \\
{[0.301]}\end{array}$ & & & $\begin{array}{r}0.578^{* * *} \\
{[0.156]}\end{array}$ \\
\hline Loss aversion & $\begin{array}{r}0.0264 \\
{[0.0160]}\end{array}$ & $\begin{array}{r}0.0102 \\
{[0.0269]}\end{array}$ & $\begin{array}{r}0.0605 \\
{[0.0553]}\end{array}$ & $\begin{array}{r}0.019 \\
{[0.0167]}\end{array}$ & $\begin{array}{c}0.00212 \\
{[0.0250]}\end{array}$ & $\begin{array}{r}0.0385 \\
{[0.0258]}\end{array}$ \\
\hline Observations & 72 & 72 & 72 & 72 & 72 & 72 \\
\hline R-squared (pseudo R2) & 0.09 & 0.10 & 0.39 & 0.02 & 0.01 & 0.27 \\
\hline Model & OLS & OLS & Probit & OLS & OLS & Probit \\
\hline
\end{tabular}

Note: In this table we examine the withdrawal behavior and beliefs of followers in the first round only. The dependent variables are Belief bank strong, Belief other and Withdraw. Columns $(3,6)$ report marginal effects of probit estimates. For definitions and mean statistics of all explanatory variables see Table 5. Robust standard errors reported in brackets. *, **, *** indicate significance at the $10 \%, 5 \%$ and $1 \%$ level respectively. 
In Table 7 we examine which of the belief channels, fundamentals-based contagion or strategic contagion have the strongest impact on the withdrawal behavior of followers in the Linkages treatment. We first confirm the significance of the two effects in a multivariate setting. The column 1 and 2 results confirm that beliefs about the asset-quality of the bank and the withdrawal propensity of the other follower are strongly related to the leaders' withdrawals in the Linkages treatment. The column 4 and 5 results confirm that both effects are absent in the No-Linkages treatment.

The column 3 results suggest that in the Linkages treatment the belief about the propensity of the other follower to withdraw has a strong and significant impact on a depositor's withdrawal behavior. The point estimate reported for Belief Other Withdraw in suggests that a decrease in this belief by 25 percentage points - which is the average effect of observing 0 as opposed to 2 leaders' withdrawals would increase the propensity of a follower to withdraw by 35 percentage points. This compares to the actual observed reduction in withdrawal rates of 50 percentage points for the case of observing 0 as opposed to 2 leaders' withdrawals. Thus strategic contagion can account for the larger share of contagion we observe in deposit withdrawals across banks in the Linkages treatment. ${ }^{13}$

The estimated impact of the belief about bank asset-quality on withdrawal behavior in the Linkages treatment is smaller and not significant. That said the economic magnitude of the coefficient estimated for Belief Strong Bank in column 3 is in line with behavior in the leaders games presented in Section 4.1. There we see that leaders which know for certainty that asset quality was strong are 13 percentage points less likely to withdraw than leaders which know the quality is weak. Similarly, the Table 7, column 3 estimates suggest that increasing the belief of assets being strong from 0 to 1 would induce a 14.9 percentage drop in withdrawals. Due to the fact that leaders' withdrawals are only an imperfect signal for asset quality, the change in beliefs about asset-quality induced by leader behavior is small in our linkages treatment. The table 5 results show that a follower who observes 0 withdrawals is only 13 percentage points more likely to believe that the bank has strong assets than a follower who observes 2 withdrawals. The impact of fundamentals-based contagion in our experiment $(.13 * .149=2 \%)$ is thus small compared to the effect of strategic contagion.

\footnotetext{
13 The strong effect of beliefs about the withdrawal propensity of the other depositor is also found for the Linkages treatment (column 6) and the Baseline treatment (not shown in the table).
} 
The novelty of our results is that the observed economic contagion that we document derives from a channel where (i) observed behavior of leaders affects followers' beliefs, and (ii) these beliefs subsequently affect withdrawals decisions. This result puts an interesting perspective on the distinction between pure-panic coordination failures vs. information-based bank run explanations. We find that beliefs about other depositors (i.e. strategic contagion) are the main driver of withdrawal behavior, as posited in the Diamond-Dybvig pure-panics framework. However, strategic contagion only arises if depositors perceive an economic linkage between their own bank and the bank they observe. Thus, behavior of depositors at another bank seems to be perceived as relevant only if it is informative for the current bank. Put in different words, the failure of a bank provides adverse information only for banks with similar features, whose depositors will respond by withdrawing their funds. This view is consistent with the information-based view on contagion.

\subsection{Persistence of Contagion and Spillover Effects}

In this section we exploit the fact that followers in all three treatments played the two-person bank-run game in two consecutive rounds. First, we use second round behavior to study whether the contagion across banks observed in Section 4.2 is persistent over time. Second, we examine to what extent withdrawal behavior is correlated with the experience of the subject in the first round.

Iyer and Puri (2012) find that there are significant long-run effects of bank-runs, with depositors who run being less likely to return to the bank. In our experiment we find congruent behavior. Contagion across banks is persistent over time. Table 8 shows first and second rounds' withdrawal rates. Clearly, the impact of the information from the leaders games remains strong in the Linkages treatment through to round 2. Similarly, in NoLinkages treatment, second round behavior seems as unaffected by contagion as first round behavior. These findings suggests that when contagion occurs across banks, the negative effects may not be short-lived only.

TABLE 8. $1^{\text {ST }}$ AND $2^{\text {ND }}$ ROUND WITHDRAWALS OF FOLLOWERS

\begin{tabular}{|c|c|c|c|c|c|c|c|}
\hline \multirow{2}{*}{$\begin{array}{r}\text { Treatment } \\
\text { \# observed withdrawals }\end{array}$} & \multicolumn{3}{|c|}{ No-Linkages } & \multicolumn{3}{|c|}{ Linkages } & \multirow{2}{*}{$\begin{array}{c}\text { Baseline } \\
\text { n.a. }\end{array}$} \\
\hline & 0 & 1 & 2 & 0 & 1 & 2 & \\
\hline Round 1 & $15.9 \%$ & $25.0 \%$ & $0.0 \%$ & $12.5 \%$ & $50.0 \%$ & $62.5 \%$ & $23.3 \%$ \\
\hline Round 2 & $15.9 \%$ & $20.8 \%$ & $25.0 \%$ & $4.2 \%$ & $45.0 \%$ & $50.0 \%$ & $31.7 \%$ \\
\hline
\end{tabular}


Negative financial experiences have significant effects on future behavior in a wide range of settings. ${ }^{14}$ For example, survey evidence by Van der Cruijsen et al. (2011) shows that depositors who experienced a bank failure/bailout during the recent financial crisis are more likely to spread their saving across multiple banks. Dubois et al. (2012) and Trautmann and Vlahu (2011) find experimental evidence that experience of a coordination failure reduces the future willingness to coordinate on the Pareto-dominant equilibrium.

In Table 9 we examine the impact of experience in round 1 on round 2 withdrawal behavior of followers. We define a dummy variable negative surprise which equals 1 if the depositor kept her funds in the bank in round 1, but the other depositor withdrew. It equals 0 if both depositors did the same action, or if the depositor withdrew while the other depositor kept her funds in the bank. Likewise, we define a dummy variable positive surprise which equals 1 if the depositor withdrew her funds from the bank in round 1 , but the other depositor did not. It equals 0 if both depositors did the same action, or if the depositor kept her deposit while the other depositor withdrew her funds from the bank.

TABLE 9: CONTAGION WITHIN BANKS - UNIVARIATE RESULTS

\begin{tabular}{|c|c|c|c|c|c|c|}
\hline \multicolumn{7}{|l|}{ Panel A } \\
\hline $\begin{array}{r}\text { Treatment } \\
\text { Negative surprise } \\
\text { Observations }\end{array}$ & $\begin{array}{r}\text { Bas } \\
\text { yes } \\
(\mathrm{n}=12)\end{array}$ & $\begin{array}{r}\text { no } \\
(\mathrm{n}=34) \\
\end{array}$ & $\begin{array}{c}\text { No-Lir } \\
\text { yes } \\
(\mathrm{n}=11)\end{array}$ & $\begin{array}{r}\text { ges } \\
(\mathrm{n}=48) \\
\end{array}$ & $\begin{array}{r}\text { Link } \\
\text { yes } \\
(\mathrm{n}=12) \\
\end{array}$ & $\begin{array}{r}\text { no } \\
(\mathrm{n}=32) \\
\end{array}$ \\
\hline $\begin{array}{l}\text { Withdrawals } \\
\text { Fisher exact test }\end{array}$ & $\begin{array}{r}50 \% \\
\mathrm{p}=0 \\
\end{array}$ & $6 \%$ & $\begin{array}{c}18 \% \\
p=0 .\end{array}$ & $6 \%$ & $\begin{array}{r}17 \% \\
\mathrm{p}=0 \\
\end{array}$ & $0 \%$ \\
\hline \multicolumn{7}{|l|}{ Panel B } \\
\hline $\begin{array}{r}\text { Treatment } \\
\text { Positive surprise } \\
\text { Observations } \\
\end{array}$ & $\begin{array}{r}\text { Bas } \\
\text { yes } \\
(\mathrm{n}=12) \\
\end{array}$ & $\begin{array}{r}\text { no } \\
(\mathrm{n}=2)\end{array}$ & $\begin{array}{c}\text { No-Lir } \\
\text { yes } \\
(\mathrm{n}=11)\end{array}$ & $\begin{array}{r}\text { no } \\
(\mathrm{n}=2) \\
\end{array}$ & $\begin{array}{r}\begin{array}{r}\text { Link } \\
\text { yes } \\
(\mathrm{n}=12)\end{array} \\
\end{array}$ & $\begin{array}{r}\text { no } \\
(\mathrm{n}=16) \\
\end{array}$ \\
\hline $\begin{array}{l}\text { Withdrawals } \\
\text { Fisher exact test }\end{array}$ & $\begin{array}{r}75 \% \\
\mathrm{p}=1\end{array}$ & $100 \%$ & $\begin{array}{c}64 \% \\
\mathrm{p}=1 .\end{array}$ & $50 \%$ & $\begin{array}{r}50 \% \\
\mathrm{p}=0\end{array}$ & $\begin{array}{l}93.75 \% \\
3 \\
\end{array}$ \\
\hline
\end{tabular}

Notes: Panel A: The sample is limited to those followers which did not withdraw in round 1 and shows the percentage of followers which did withdraw in round 2 depending on whether they experienced a negative surprise in round 1 . Panel B: The sample is limited to those followers which did withdraw in round 1 and shows the percentage of followers which did withdraw in round 2 depending on whether they experienced a positive surprise in round 1.

\footnotetext{
${ }^{14}$ See Bracha and Jamison (2012), Dubois et al. (2012), Malmedier and Nagel (2011), Rozin and Royzman (2001), Trautmann and Vlahu (2011), and Van der Cruijsen et al. (2011).
} 
In all three treatments, withdrawal rates are higher after a negative surprise than after a neutral experience. However, the effect is significant in Baseline and Linkages treatments only. Conducting a similar analysis for positive surprises reveals no positive effects in Baseline or No-Linkages, and a positive effect in Linkages. However, the latter effect is driven by the fact that depositors who withdrew in round 1 and did not experience a positive surprise became almost certain to withdraw (93.95\%). Those with a positive surprise still show very high withdrawal rates of $50 \%$. Thus, we can argue that once contagion takes place in the presence of economic linkages, there is evidence for propagation of contagion effects within banks. The observed pattern suggests that in the long-run negative experiences seem to dominate and lead to higher rates of bank failure than in the short-run, as previously found in Trautmann and Vlahu (2011) or Dubois et al. (2012). For the situation with an initial crossbank contagious shock, these findings imply persistence, and possibly amplification of the initial negative shock. ${ }^{15}$

\section{Discussion and Concluding Remarks}

We conduct a laboratory experiment to examine under which circumstances a depositor-run at one bank may lead to a depositor-run at another bank. Our results suggest that deposit withdrawals can be strongly contagious across banks when there are economic linkages between banks' balance sheets. By contrast we find no evidence for contagion of deposit withdrawals between banks without such economic linkages.

Our findings strongly support the conjecture that "because moving away from a good equilibrium requires a large change in beliefs, the initiation of a run when none was expected requires something that all (or nearly all) depositors see (and believe that others see)" (Diamond 2007, p.197). Our results suggest that a run on another bank is likely to constitute an event which leads to substantial changes in beliefs among depositors, and thus that bank runs may indeed be contagious. However, our results also emphasize that a depositor run at one bank will only lead to a change in beliefs at a second bank if depositors know that there

\footnotetext{
${ }^{15}$ Interestingly, withdrawals did not increase in round 2 of the Linkages treatment with at least one observed withdrawal despite the negative surprise effect. This is due to the fact that the number of withdrawals was already very high, and that $20 \%(5 / 25)$ of the depositors who withdrew in round 1 made an attempt to coordinate on keeping the deposits in round 2. Clearly, coordination failure was very costly to subjects, and a dynamic multi round approach would be needed to shed more light on the dynamics of contagion spillover effects.
} 
are substantial economic linkages between the two banks. As such, we contribute to explaining the limited degree of contagion across banks as documented by Calomiris and Mason (1997) or Saunders and Wilson (1996) for the period of the Great Depression.

From a policy perspective our findings suggest that economic linkages between banks due to common asset exposure and/or similar portfolio characteristics may have a further negative impact on financial stability beyond their direct economic impact on banks financial statements and equity returns. ${ }^{16}$ Economic linkages between banks give rise to contagion of deposit withdrawals across banks, especially when depositors are aware of these economic linkages. Such systemic problems can be more acute for banking systems characterized by clusters of domestic banks which share the same business model (e.g., cajas in Spain or Landesbanken in Germany). Our results are consistent with theories of Acharya (2009), Ibragimov et al. (2011) and Wagner (2010), and provide empirical evidence for the dark side of diversification by pointing to the negative externalities of lack of diversity on the asset side of financial institutions. While diversification at individual bank lowers bank's risk, a more homogenous financial system in which banks have become too similar to each other by investing in the same assets and getting access to the same markets, is more prone to systemic risk triggered by contagion effects. In particular, runs at financial institutions, both in traditional and novel forms (e.g., repo runs or termination of roll-over short-term contracts by wholesale creditors) can be triggered by the propagation of liquidity problems at other financial institutions. For regulators this accentuates the question of how to monitor and regulate economic linkages between banks stemming from similar exposures, in order to mitigate financial fragility and to encourage greater diversity in the financial system. ${ }^{17}$

Our findings may also inform the discussion about information disclosure and stability in the financial sector. In our experiment followers did not have perfect information about the asset-quality of their bank. But they did have perfect information about whether their bank had economic linkages with the leaders' bank. Our results suggest that transparency about economic linkages between banks may foster contagion of deposit withdrawals across banks.

\footnotetext{
${ }^{16}$ Aharony and Swary (1983, 1996), Goldsmith-Pinkham and Yorulmazer (2010), and Swary (1986) show that banks with similar characteristics to those of the failed banks are very likely to experience negative abnormal equity returns.

${ }^{17}$ See Acharya and Yorulmazer (2007, 2008a, and 2008b) for theories on how banks, due to limited liability which allows them to not fully internalize the cost of failure, choose endogenously highly correlated portfolios to increase the likelihood of joint failure and regulatory bailout.
} 
Whether less transparency about the existence (or non-existence) of linkages between banks would lead to less (or more) contagion is a question we leave open for future research.

While our findings provide novel insights on the drivers of contagious bank runs, our results should be interpreted with care. First, our results are derived from a two-person coordination game. It is possible that contagion of bank runs due to purely psychological linkages, which did not arise in our experiment, might be more likely to occur in larger networks of depositors. Second, our experimental design modeled economic linkages as a correlation of asset returns (e.g. common asset exposure). It is possible that the impact of economic linkages between banks on bank-run contagion to be different in a context of mutual interbank or payment-system exposures. Further research is thus necessary to test the robustness of our findings to the economic context in which depositor runs may take place and to assess the overall effect of information contagion in presence of common exposures and other potential channels through which contagion in the banking sector may occur.

\section{References}

Acharya, V. (2009), A Theory of Systemic Risk and Design of Prudent Bank Regulation, Journal of Financial Stability, 5, 224-255.

Acharya, V. and T. Yorulmazer (2007), Too-Many-to-Fail - An Analysis of TimeInconsistency in Bank Closure Policies, Journal of Financial Intermediation, 16, 1-31.

Acharya, V. and T. Yorulmazer (2008a), Information Contagion and Bank Herding, Journal of Money, Credit and Banking, 40(1), 215-231.

Acharya, V. and T. Yorulmazer (2008b), Cash-in-the-Market Pricing and Optimal Resolution of Bank Failures, Review of Financial Studies, 21(6), 2705-2742.

Aharony, J. and I. Swary (1983), Contagion Effects of Bank Failures: Evidence from Capital Markets, Journal of Business, 56, 305-322.

Aharony, J. and I. Swary (1996), Additional Evidence on the Information-Based Contagion Effects of Bank Failures, Journal of Banking and Finance, 20, 57-69. 
Ahnert, T. and C.-P. Georg (2012), Information Contagion and Systemic Risk, Working Paper, LSE.

Ai, C. and E. Norton (2003), Interaction Terms in Logit and Probit Models, Economics Letters, 80, 123-129.

Allen, F., T. Beck, E. Carletti, P. R. Lane, D. Schoenmaker, and W. Wagner (2011), CrossBorder Banking in Europe: Implications for Financial Stability and Macroeconomic Policies”, CEPR Report, London.

Allen, F. and D. Gale (2000), Financial Contagion, Journal of Political Economy, 108, 1-33.

Bracha, A. and J. Jamison (2012), Shifting Confidence in Home Ownership: The Great Recession, B.E. Journal of Macroeconomics, forthcoming.

Brown, M. and C. Zehnder (2007), Credit Reporting, Relationship Banking and Loan Repayment, Journal of Money, Credit and Banking, 39(8), 1883-1918.

Brown, M. and C. Zehnder (2010), The Emergence of Information Sharing in Credit Markets, Journal of Financial Intermediation, 19(2), 255-278.

Brunnermeier, M. and L.H. Pedersen (2009), Market Liquidity and Funding Liquidity, Review of Financial Studies, 22(6), 2201-2238.

Bryant, J. (1980), A Model of Reserves, Bank Runs, and Deposit Insurance, Journal of Banking and Finance, 4, 335-44.

Cachon, G. P. and C.F. Camerer (1996), Loss-Avoidance and Forward Induction in Experimental Coordination Games, Quarterly Journal of Economics, 111, 165-194.

Calomiris, C. W. and C. M. Kahn (1991), The Role of Demandable Debt in Structuring Optimal Banking Arrangements, American Economic Review, 81, 497-513.

Calomiris, C. W. and J. R. Mason (1997), Contagion and Bank Failures during the Great Depression: The June 1932 Chicago Banking Panic, American Economic Review, 87(5), 863-83.

Camerer, C.F. (2003), Behavioral Game Theory: Experiments in Strategic Interaction, Princeton University Press. 
Chari, V.V. and R. Jagannathan (1988), Banking Panics, Information, and Rational Expectations Equilibrium, Journal of Finance, 43(3), 749-761.

Chen, Y. (1999), Banking Panics: The Role of First-Come, First-Served Rule and Information Externalities, Journal of Political Economy, 107(5), 946-968.

Dasgupta, A. (2004), Financial Contagion Through Capital Connections: A Model of the Origin and Spread of Bank Panics, Journal of the European Economic Association, 2(6), 1049-1084.

De Graeve, F. and A. Karas (2010), Identifying VARs through Heterogeneity: An Application to Bank Runs, Sveriges Riksbank Working Paper No. 244.

Degryse, H., M. Kim, and S. Ongena (2009), Microeconometrics of Banking: Methods, Applications and Results, Oxford University Press.

Diamond, D.W. (2007), Banks and Liquidity Creation: A Simple Exposition of the DiamondDybvig Model, Federal Reserve Bank of Richmond Economic Quarterly, 93, 189-200.

Diamond, D.W. and P.H. Dybvig (1983), Bank Runs, Deposit Insurance and Liquidity, Journal of Political Economy, 19, 401-413.

Dubois, D., M. Willinger, and P. van Nguyen (2012), Optimization Incentives and Relative Riskiness in Experimental Coordination Games, International Journal of Game Theory, 41(2), 369-380.

Fehr, E. and C. Zehnder (2009), Reputation and Credit Market Formation: How Relational Incentives and Legal Contract Enforcement Interact, IZA Discussion Paper No. 4351.

Financial Times (2008), Latvia Takes Over Parex after Run on Bank, November 9, http://www.ft.com/intl/cms/s/0/bc3b322e-ae92-11dd-b621-000077b07658.html\#axzz256kSFxuG.

Financial Times (2009), Dutch Central Bank Takes Over DSB, October 12, http://www.ft.com/intl/cms/s/0/5184b774-b71b-11de-96f2-00144feab49a.html\#axzz2A6gvVZDr.

Fischbacher, U. (2007), Z-Tree: Zurich Toolbox for Ready-Made Economics Experiments, Experimental Economics, 10, 171-178. 
Freixas, X. and B. Parigi (1998), Contagion and Efficiency in Gross and Net Interbank Payment Systems, Journal of Financial Intermediation, 7(1), 3-31.

Freixas, X., B. Parigi, and J. C. Rochet (2000), Systemic Risk, Interbank Relations and Liquidity Provision by the Central Bank, Journal of Money, Credit and Banking, 32(2), 611-638.

Freixas, X. and J. C. Rochet (2008), Microeconomics of Banking, MIT Press.

Furfine, C.H. (2003), Interbank Exposures: Quantifying the Risk of Contagion, Journal

of Money, Credit and Banking, 35, 111-128.

Gächter, S., E. J. Johnson, and A. Herrmann (2007), Individual-Level Loss Aversion in Risky and Riskless Choice, Working Paper, Nottingham.

Garratt, R. and T. Keister (2009), Bank Runs: An Experimental Study, Journal of Economic Behavior and Organization, 71(2), 300-317.

Goldsmith-Pinkham, P. and T. Yorulmazer (2010), Liquidity, Bank Runs and Bailouts: Spillover Effects during the Northern Rock Episode, Journal of Financial Services Research, 37(2-3), 83-98.

Goldstein, I. and A. Pauzner (2005), Demand-Deposit Contracts and the Probability of Bank Runs, Journal of Finance, 60, 1293-327.

Ibragimov, R., D. Jaffee, and J. Walden (2011), Diversification Disasters, Journal of Financial Economics, 99, 333-348.

Iyer, R. and J.L. Peydro-Alcalde (2011), Interbank Contagion at Work: Evidence from a Natural Experiment, Review of Financial Studies, 24, 1337-1377.

Iyer, R. and M. Puri (2012), Understanding Bank Runs, American Economic Review, forthcoming.

Jacklin, C. J. and S. Bhattacharya (1988), Distinguishing Panics and Information-Based Bank Runs: Welfare and Policy Implications, Journal of Political Economy, 96, 568-92. 
Kiss, H.J., I.Rodriguez-Lara, and A.Rosa-Garcia (2011), On the Effects of Deposit Insurance and Observability on Bank Runs: An Experimental Study, Journal of Money Credit and Banking, forthcoming.

Kiss, H.J., I.Rodriguez-Lara, and A.Rosa-Garcia (2012), Do Social Networks Prevent Bank Runs? ERICES Discussion Paper in Economic Behaviour No.8.

Madies, P. (2006), An Experimental Exploration of Self-fulfilling Banking Panics: Their Occurrence, Persistence, and Prevention, Journal of Business, 79(4), 1831-1866.

Malmedier, U. and S. Nagel (2011), Do Macroeconomic Experiences Affect Risk-Taking?, Quarterly Journal of Economics, 126(1), 373-416.

Mistrulli, P. E. (2011), Assessing Financial Contagion in the Interbank Market: Maximum Entropy versus Observed Interbank Lending Patterns, Journal of Banking and Finance, 35(5), 1114-1127.

Postlewaite, A. and X. Vives (1987), Bank Runs as an Equilibrium Phenomenon, Journal of Political Economy, 95, 485-91.

Rochet, J.-C. and J. Tirole (1996), Interbank Lending and Systemic Risk, Journal of Money Credit and Banking, 28, 773-762.

Rozin, P. and E. B. Royzman (2001), Negativity Bias, Negative Dominance, and Contagion, Personality and Social Psychology Review, 5, 296-320.

Rydval, O. and A. Ortmann (2005), Loss Avoidance as Selection Principle: Evidence from Simple Stag-Hunt Games, Economics Letter, 88, 101-107.

Saunders, A. and B. Wilson (1996), Contagious Bank Runs: Evidence from the 1929-1933 Period, Journal of Financial Intermediation, 5(4), 409-423.

Schotter, A. and T. Yorulmazer (2009), On the Dynamics and Severity of Bank Runs: An Experimental Study, Journal of Financial Intermediation, 18, 217-241.

Swary, I. (1986), Stock Market Reaction to Regulatory Action in the Continental Illinois Crisis, Journal of Business, 59, 451-473. 
Telegraph (2012a), Deposit Flight from Spanish Banks Smashes Record in July, August 28, http://www.telegraph.co.uk/finance/financialcrisis/9504911/Deposit-flight-from-Spanish-banks-smashesrecord-in-July.html

Telegraph (2012b), Withdrawals at Santander UK amid Spain Fears, May 18, http://www.telegraph.co.uk/finance/personalfinance/consumertips/banking/9276164/Withdrawals-at$\underline{\text { Santander-UK-amid-Spain-fears.html }}$

Trautmann, S. and R. Vlahu (2011), Strategic Loan Defaults and Coordination: An Experimental Analysis, Journal of Banking and Finance, forthcoming.

Upper, C. (2011), Simulation Methods to Assess the Danger of Contagion in Interbank Markets, Journal of Financial Stability, 7, 111-125.

Upper, C. and A. Worms, A. (2004), Estimating Bilateral Exposures in the German Interbank Market: Is There a Danger of Contagion? European Economic Review, 8, 827-49.

Van der Cruijsen, C., J. de Haan, D.-J. Jansen, and R. Mosch (2011), Household Savings Behavior in Crisis Times, DNB Working Paper No. 315.Van Lelyveld I. and F. Liedorp (2006), Interbank Contagion in the Dutch Banking Sector: ASensitivity Analysis, International Journal of Central Banking, 2, 99-133.

Wagner, W. (2010), Diversification at Financial Institutions and Systemic Crises, Journal of Financial Intermediation, 19, 333-354.

Wells, S. (2004), Financial Interlinkages in the United Kingdom’s Interbank Market and the Risk of Contagion, Bank of England Working Paper No. 230. 